\title{
RESTRICTED ACCESS TO ARBITRAL REVIEW OF DISMISSAL: RECENT DEVELOPMENTS IN ALBERTA AND RECOMMENDATIONS FOR A NEW APPROACH
}

\section{IAN B. MCKENNA*}

The author reviews the issue of the rights of provincial government employees to have their dismissals adjudicated by an independant arbitrator who would have the power of reinstatement if the employer lacked cause for the dismissal. Particular emphasis is placed on the status of casual, temporary and probationary employees under the Alberta Public Service Labour Relations Act. The author then concludes by recommending a "statutory policy" approach to the issue.
L'auteur étudie la question des droits des fonctionnaires provinciaux qui ont été congédiés. Ont-ils le droit de porter la décision de congédiement devant un arbitre impartial, lequel serait investi du pouvoir de réintégration du fonctionnaire si la décision de l'employeur était sans fondement? L'accent porte surtout sur le statut du personnel intermittent, temporaire et stagiaire aux termes de la Public Service Labour Relations Act de l'Alberta. $L$ 'auteur conclut en recommandant la perspective d'une «politique statutaire".

\section{TABLE OF CONTENTS}

I. INTRODUCTION $\ldots \ldots \ldots \ldots \ldots \ldots \ldots \ldots \ldots \ldots \ldots . \ldots \ldots$

II. THE "CONTRACTUAL INTERPRETATION" APPROACH TO

ARBITRAL REVIEW $\ldots \ldots \ldots \ldots \ldots \ldots \ldots \ldots \ldots \ldots \ldots \ldots$

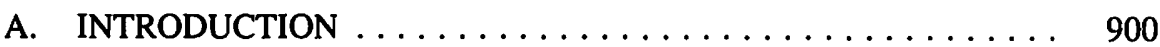

B. UNION CHALLENGES TO COLLECTIVE AGREEMENTS .... 901

C. A NEW UNION APPROACH UNDER THE PSERA . . . . . . . . 903

D. LEGISLATIVE RESPONSE TO THE BOARD'S DECISION .... 904

E. THE LETHBRIDGE COMMUNITY COLLEGE CASE . . . . . . 905

1. The Employer's Case . . . . . . . . . . . . . . . . 905

2. The Union's Argument and the Board's Decision ........ 906

(a) Was There a "Difference"? . . . . . . . . . . . . 906

(b) Which "Differences" Are to be Resolved Under the Collective Agreement? . . . . . . . . . . . . . 907

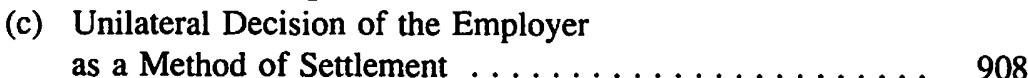

3. The Court of Queen's Bench Decision ............... 909

4. Assessment of the Court's and the Board's Decisions ...... 909

(a) The Court's Decision .................... 909

(b) The Board's Decision ............... 911

III. RECOMMENDATIONS FOR A "STATUTORY POLICY"

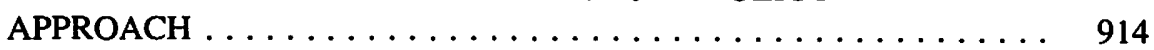

A. LIMITATIONS OF THE BOARD'S APPROACH $\ldots \ldots \ldots \ldots .914$

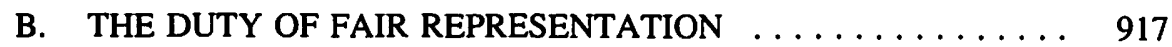

C. DUTY TO BARGAIN IN GOOD FAITH $\ldots \ldots \ldots \ldots \ldots \ldots 920$

IV. SUMMARY AND CONCLUSIONS $\ldots \ldots \ldots \ldots \ldots \ldots \ldots \ldots . \ldots 21$ 


\section{INTRODUCTION}

Collective agreements in Canada commonly seek to deny probationary, temporary or casual employees arbitral review of dismissal, typically available to seniority-rated members of the bargaining unit. Throughout the last decade, the legality of such restrictions has been challenged as being in violation of the requirement, common to the labour legislation of each Canadian jurisdiction, that a collective agreement contain a method for the final and binding settlement of differences arising from the agreement.'

This paper outlines the basis of the legal challenges under the Alberta Public Service Employee Relations Act (PSERA) and examines critically the different "contract interpretation" approaches taken by the Public Service Employee Relations Board (the Board) and the courts.

It is contended that access to arbitral review of dismissal is the traditional quid pro quo for legislative restrictions on employees' freedom to strike. Encroachments on such access are most effectively resisted, not according to the contingencies of collective agreement language, but on the basis of statutory policy embodied in the exclusive jurisdiction of an arbitrator (adjudicator) to settle differences, the trade union duty of fair representation and the employer duty to bargain in good faith.

\section{THE "CONTRACTUAL INTERPRETATION" APPROACH TO ARBITRAL REVIEW}

\section{A. INTRODUCTION}

At common law, an employer's legal requirement is to provide an employee reasonable notice of termination or pay in lieu thereof. ${ }^{2}$ Substantially better protection against unjust dismissal is typically negotiated by unions in collective agreements, which normally provide for an internal grievance procedure with a final step of binding arbitral review of the justice of a dismissal.

The requirement of binding arbitration of disputes arising from collective agreements is typically entrenched in provincial and federal labour relations legislation which, as noted above, "write in" a model arbitration clause to deficient collective agreements. ${ }^{3}$

Employers with sufficient bargaining power have negotiated collective agreement language purporting to deny such categories as probationary, temporary and casual

1. For example, The Public Service Employee Relations Act, R.S.A. 1980 c.P-33 as am., s.61; the Labour Relations Code, S.A. 1988, c.L-1.2, s. 133; Ontario Labour Relations Act, R.S.O. 1980, c.228, s.44(1).

2. See, for example, H.W. Arthurs, D.D. Carter and H.J. Glasbeck, Labour Law and Industrial Relations in Canada (2nd.ed.) (Kluwer/Butterworths, 1984) at 121-123. Termination for cause may be undertaken without notice.

3. Supra, note 1. See PSERA, s.63 and the Labour Relations Code, s.134. 
employees' protection against summary dismissal, and to exclude such dismissal from arbitral review.

\section{B. UNION CHALLENGES TO COLLECTIVE AGREEMENTS}

More than a decade ago, unions began to challenge the differential treatment of probationary and casual employees with respect to arbitral review of dismissal. In the Toronto Hydro-Electric System case, ${ }^{4}$ arbitrator Barton ruled void a collective agreement provision which purported to withdraw from probationary employees the right to grieve their dismissal. The collective agreement granted all bargaining unit employees the right to be terminated only for just cause, and the arbitrator ruled that the purported exclusion of probationers from arbitration was contrary to the statutory requirement of a final and binding method of settling disputes arising from the collective agreement. The arbitrator's approach was upheld by both a majority of the Ontario Divisional Court ${ }^{5}$ and by the Ontario Court of Appeal, ${ }^{6}$ opening the door for a number of successful challenges of collective agreements that purported to withhold from certain categories of employee the right to arbitral review of their dismissal. ${ }^{7}$

However, the success of such challenges were contingent upon the requirement that the employee seeking arbitral review had first to establish a substantive right under the collective agreement not to be dismissed without cause. The Alberta case of Cherneski ${ }^{8}$ illustrates this point. Cherneski, a casual employee, grieved her dismissal. The collective agreement protected regular employees from dismissal without cause, but casual employees were subject to dismissal without cause and without access to the grievance and adjudication procedures available to regular employees under the collective agreement.

In accepting jurisdiction and ruling Cherneski's dismissal improper, the adjudicator held that, by purporting to exclude her from the grievance procedure, the collective agreement contravened s.61 of the Public Service Employee Relations Act (PSERA), which provided: ${ }^{9}$

Every collective agreement shall contain provisions for the final settlement by

(a) adjudication or

(b) some other method that may be agreed by the parties or persons bound by the collective agreement of differences between the parties or persons bound by the collective agreement.

4. Re Toronto Hydro-Electric System (1980), 26 L.A.C. (2d) 434 (Barton).

s. (1980), 111 D.L.R. (3d) 693.

6.

(1981), 113 D.L.R. (3d) 512.

Re Ontario Hydro and Ontario Hydro Employees' Union, Local 1000 (1983) 147 D.L.R. (3d) 210. Adjudicator's award unreported. Court of Appeal decision reported at (1985), 36 Alta. L.R. (2d) 253. Supra, note 1. S.61 was subsequently amended by the Public Service Employee Relations Amendment Act, S.A. 1985, c.47, s.5. 
The grievor submitted that, by denying her access to the offended s.61 of the PSERA and activated s.63, which provides a model clause for the adjudication of differences arising from the interpretation, application, operation, contravention or alleged contravention of the collective agreement. In the grievor's view, the provisions of $\mathrm{s} .63^{10}$ were automatically "written into" the collective agreement because the agreement failed to meet the requirements of $s .61$.

In reply, the employer contended, firstly, that the complaint was not a "difference", defined in the Act as any difference arising from the interpretation, application, operation or alleged contravention of the collective agreement or as to whether such difference can be the subject of adjudication." The employer noted that the collective agreement reserved to management all functions and rights not specifically abridged or modified by the agreement, and argued that the employer's common law right to dismiss at pleasure was protected, thereby with respect to casual employees such as Cherneski. The complaint was not a "difference", submitted the employer, because the collective agreement conferred on the employee no substantive right with respect to dismissal from which a "difference" could arise. In the absence of such a "difference", there was no infringement of s.61, and s.63 was, therefore, inapplicable.

Alternatively, the Crown argued that even if the complaint were a "difference" within the meaning of the Act, the collective agreement provided a method other than adjudication for its settlement, namely, the unilateral decision of the employer. Such unilateral power of decision was reserved as a management right unabridged by the collective agreement.

The Court of Queen's Bench ${ }^{12}$ accepted the employer's second argument and quashed the adjudication board's award as beyond its jurisdiction. Upon appeal, the Court of Appeal ${ }^{13}$ upheld the Chambers judge's order of certiorari, but not on the basis of the argument that found favour with the Court of Queen's Bench. Instead, it found that, absent any substantive right under the collective agreement not to be dismissed, the grievor's complaint of dismissal was not a "difference" for the purposes of the Act.

10. Unlike s.61, s.63 was not amended in 1985 (supra, note 9).

11. Supra, note 8 at 255.

12. [Unreported] (Alta. Q.B.).

13. Supra, note 8. The AUPE's lack of success in Cherneski has encouraged its pursuit of technicalities to circumvent the restrictions on adjudication for probationers, casual employees, etc. See various unreported decisions of the Public Service Grievance Appeal Board (1) Re a Grievance by Valerie Wiebe, (Sept. 1983), Ref. No. 155-001-502-150, where the Appeal Board declined jurisdiction to hear the merits of the grievance in light of the restricted access of casual employees to adjudication. (2) In Re a Grievance by Peter McClure, (June 1983), Ref. No. 155-001-502-145, the Appeal Board declined to hear the merits of a probationer's grievance of dismissal, but declared level 3 of the internal procedure a nullity and referred the matter back to level 3 for a new and final decision. (3) In Re Grievance by Joanne Massey. (Aug. 1984), Ref. No. 155-001-502-192, the Appeal Board heard the grievance on its merits because the employer had mistakenly terminated the probationer after the expiry of the period of probation. 
The Court of Appeal's approach in Cherneski is consistent with the accepted view that a statutory requirement for arbitration of disputes arising under a collective agreement does not apply to a dismissed employee who has no substantive protection against dismissal under the collective agreement.

The Court's approach was followed by the Alberta Labour Relations Board in Kliparchuk v. Edmonton Police Department. ${ }^{14}$ The applicant, a former probationary police officer, asked the Labour Relations Board to answer the question "can the terms of a collective agreement properly exclude a probationary employee from grieving his release from employment?" in light of ss. 20 and 21 of the Police Officers Collective Bargaining Act (POCBA). ${ }^{15}$ The Labour Relations Board observed that, as the collective agreement precluded arbitral review of a probationer's dismissal, it excluded the release of a probationer from the meaning of "difference" and precluded arbitral review of his dismissal.

\section{A NEW UNION APPROACH UNDER THE PSERA}

The Union's failure in Cherneski caused it to shift the basis of its "statutory policy" argument. In the 1984 bargaining of the renewal of the provincial master agreement, the AUPE and the Crown reached an impasse on grievance and adjudication procedures. The employer proposed dismissal of probationary, casual and temporary employees at its own discretion, with no access to arbitral review, while the Union proposed that the collective agreement contain no grievance of adjudication procedure whatsoever.

In the event of impasse, the Board is empowered to refer to arbitration ${ }^{16}$ all matters in dispute, except those excluded by subsections 48(1) and (2) of the PSERA, and, initially, it ruled both proposals non-arbitrable. ${ }^{17}$ The Board reasoned that s.48(1) permitted arbitration only of matters that may be contained in a collective agreement and that neither proposal met such a test by virtue of s.61, which required the settlement of all "differences" arising from the collective agreement by adjudication, in the absence of some other agreed upon method of settlement. The effect of such decision would have been to activate the model adjudication clause provided by $\mathrm{s.63}$ of the Act.

However, upon reconsideration, the Board ruled both proposals arbitrable, with a caution to the arbitration board that, "to the extent that the collective agreement grants substantive rights to employees, such rights cannot be undermined by a provision denying employees access to adjudication, given the provisions of s.61(a) of the Act". ${ }^{18}$

Evidently, the Board was unwilling to rule "in theory" on arbitrability without advance knowledge of whether the collective agreement that would eventually emerge from

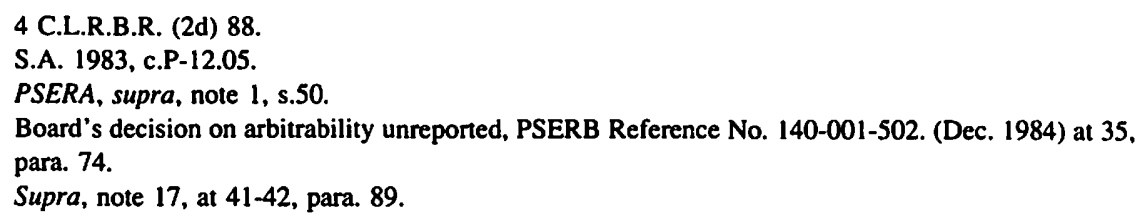


arbitration would confer substantive rights on the relevant employees with respect to dismissal or termination. If no such rights were to be entrenched, the Board reasoned, it would be open to the arbitrator to accept a proposal to exclude the relevant employees from the grievance or adjudication procedures. On the other hand, if the prospective collective agreement conferred a substantive right with respect to such issues, it would not be open to the arbitrator to deny employees access to grievance and arbitration procedures to settle "differences" arising from such substantive rights.

In the Crown's application for judicial review to strike from the Board's decision the cautionary direction to the arbitrator, the Honourable Associate Chief Justice Tevie H. Miller held the Board's direction to be obiter dictum, but found that the Court had no jurisdiction to strike out part of a tribunal's ruling while leaving the basic decision intact. ${ }^{19}$ The legal effect of the inclusion of the cautionary direction was not tested further, as the parties agreed, without resort to arbitration, to a grievance and adjudication procedure.

\section{LEGISLATIVE RESPONSE TO THE BOARD'S DECISION}

There was evident anxiety within the Alberta government over the Board's approach to the policy embodied in ss. 48(1) and 61 of the PSERA and it responded quickly by amending s. 61 to read: ${ }^{20}$

Every collective agreement shall contain a method for the settlement of differences arising

(a) as to the interpretation, application or operation of a collective agreement;

(b) with respect to a contravention or alleged contravention of a collective agreement; and

(c) as to whether a difference referred to in clause (a) or (b) can be the subject of adjudication between the parties or persons bound by the collective agreement.

The purpose of the amendment appears to have been to reduce the probability that an adjudication tribunal would reject any proposal to deny arbitral review in respect of the dismissal of certain classes of employee. ${ }^{21}$ By substituting "a method of settlement" for "adjudication or an agreed method of settlement", the Legislature clearly aimed to strengthen the argument that the employer's unilateral determination of dismissal is "a method of settlement" and, therefore, an appropriate subject for arbitration, notwithstanding s.48(1) of the Act.

\section{E. THE LETHBRIDGE COMMUNITY COLLEGE CASE}

19. Her Majesty in Right of Alberta and PSERB and Alberta Union of Provincial Employees, [Unreported] (April, 1985) (Miller, Hon. A.C.J.).

20. Supra, note 9.

21. While the amending Bill 30 was debated in the Legislature, s.5 was not; Hansard. 2Oth Legislature 3rd Session 1985 v.2. pp. 1077-78, 1090 (2nd. reading) and 1311-14 (Committee). One assumes the Government was aware of the Court of Queen's Bench decision in Re Royal Alexandra Hospital (below, note 25) interpreting a Labour Relations Act provision identical to the amended version of PSERA s.61. 
The first test of the amended legislation arose out of the 1986-87 bargaining between the AUPE (Alberta Union of Provincial Employees) and the Lethbridge Community College. The employer proposed a management right to dismiss or terminate "unsatisfactory" employees classified as "casual", "temporary" or "probationary". Such dismissal was to be without notice and without the arbitral review available to other employees covered by the collective agreement. The Board ruled arbitral the proposed managerial power to dismiss without notice but declined to refer to arbitration the proposed clause "without access to the grievance procedure". ${ }^{22}$ Such proposal was held to infringe s.61 and to be non-arbitral by virtue of s.48(1) of the Act. The Court of Queen's Bench set aside the Board's decision and directed it to refer to arbitration the proposed restriction of access to the grievance and arbitration procedure. ${ }^{23}$ That decision is before the Court of Appeal.

\section{The Employer's Case}

Before the Board, the employer argued that its proposals were arbitral in their entirety because nothing contained in s.48(2) of the Act rendered non-arbitrable the proposals to terminate certain employees without notice and without recourse to the grievance procedure.

The employer submitted further that denying access to the grievance procedure was not prohibited by the Act if no "difference" arose or could arise between the parties. Referring to the Court of Appeal's decision in Cherneski, the employer contented that no "difference" could arise from its proposal because dismissal and termination would be reserved as management rights, with respect to the specified classes of employees in question. In other words, the employer viewed its proposal as giving rise to no substantive right on the part of the employee from which a "difference" could arise. In the absence of any potential "difference" between the parties, s.61 was inapplicable and the arbitrator would be free to consider the clause restricting access to the grievance and adjudication procedure. ${ }^{24}$

The employer's final argument before the Board was that, even if its proposals could be construed as creating a potential "difference" between the parties, the decision of Justice McFadyen in Royal Alexandra Hospital ${ }^{5}$ supported the proposition that a method for the settlement of differences can include the unilateral decision of an employer, as contemplated by the employer's proposals in the Lethbridge Community College case. Employees, [Unreported] PSERB Reference No. 140-063-502 (Jan. 1988).

23. [Unreported] (Feb. 1989) (Court of Queen's Bench), Calgary, Action No. 8801-03193, (Hutchinson, J.).

24. Supra, note 22 at 12 .

25. Re Royal Alexandra Hospital and Alberta Hospital Employees' Union, Local 41 (1982), 127 D.L.R. (3d) 312 at 319 . 
Before Hutchinson J. of the Court of Queen's Bench, ${ }^{26}$ the employer argued further that s. 61 of the Act is not concerned with interest arbitration or with the formation of the collective agreement. In the employer's view, it was inconsistent with the general scheme and purposes of the Act for the Board to use s.61 of the Act to render non-arbitrable an issue that is not precluded from arbitration by s.48(2) of the Act.

\section{The Union's Argument and the Board's Decision}

The AUPE's arguments, accepted by the Board, were, in summary, as follows: a collective agreement which grants substantive rights to an employee gives rise to a potential "difference" under s.61 of the Act, and such rights cannot be undermined by a provision denying affected employees access to the dispute resolution method contained in the applicable collective agreement. ${ }^{27}$

The Union argued, and the Board agreed, that all "differences" as defined in s.61 must be resolvable by the method prescribed in the collective agreement, unless otherwise agreed by the parties. If the parties do not agree on the method to be utilized for settling differences, the method can be imposed by an arbitration board. However, the Board ruled, it is not open to the arbitration board to determine that certain "differences" between the parties will not be settled by the method of settlement contained in the collective agreement. ${ }^{28}$

The Board rejected the employer's suggestion that a method of settlement of "differences" as defined in s.61 can be the binding unilateral decision of the employer or of any party to the dispute. Such method must be an impartial dispute resolution mechanism. In the Board's opinion, the employer's proposals for dismissing or terminating "unsatisfactory" employees of particular classes would limit the employer's exercise of discretion, thus creating for employees certain substantive rights with respect to dismissal or termination. Accordingly, a "difference" could arise and the proposed restricted access to grievance and adjudication procedures was contrary to 5.61 and non-arbitrable by virtue of s.48(1) of the Act.

\section{(a) Was There a "Difference"?}

In determining that the employer's proposals would give rise to potential "differences", the Board distinguished the Cherneski case. In that case, the collective agreement reserved for management the unfettered discretion to dismiss or terminate the grievor. The Board concurred with the Court of Appeal's view in Cherneski ${ }^{29}$ that, in such circumstances, no "difference" could arise between the parties, so that $s .61$ was inapplicable. However, in the present case, the Board observed that the employer's proposal did not contemplate an unfettered right on the employer's part to dismiss or terminate. By proposing that "unsatisfactory" employees be terminated, the employer 
opened the door for a potential "difference" between the parties that did not arise in the Cherneski case. For example, according to the Lethbridge Community College's proposal, a dismissed employee could contend that she was not "unsatisfactory".

The Board's approach was that of the arbitrator in Re Toronto Printing Pressmen and Assistants' Union Local No. 10 and Council of Printing Industries of Canada, ${ }^{30}$ where the employer had discretion under the collective agreement in the classification of employees for the purposes of lay-off during a temporary shutdown of operations. That board of arbitration held that the employer was required to exercise its discretion in a reasonable manner, without discrimination, bad faith or arbitrariness. Upon judicial review, the Ontario Court of Appeal ${ }^{31}$ determined that, on a reasonable construction of the collective agreement, the arbitration board was entitled to reach its conclusion.

The Board relied, too, on the approach of the Ontario Court of Appeal in Re Ontario Hydro and Ontario Hydro Employees' Union, Local 1000,32 where the court was called upon to determine whether or not a "difference" existed within the meaning of s.37(1) of the Labour Relations Act. ${ }^{33}$ The Court observed: ${ }^{34}$

... if the arbitrator interprets the agreement as conferring on the complaining employee a right assertible in the circumstances against the employer, then there is a "difference" within the meaning of this word... in $s .37(1)$...

In the Lethbridge Community College ${ }^{35}$ case, the Board construed the employer's proposals for the termination of "unsatisfactory" employees as limiting the employer's discretion, conferring substantive rights on the relevant classes of employees and giving rise to potential "differences" within the meaning of s.61 of the Act.

\section{(b) Which "Differences" Are to be Resolved Under the Collective Agreement?}

The Board determined that the parties to a collective agreement are free to surrender the right to resolve "differences" in a particular way. The AUPE did so in the collective agreement from which the Cherneski case arose. The Board determined also that an arbitrator under the PSERA is free to determine the method of settlement of "differences" to be contained in a collective agreement in the absence of agreement between the parties. However, it held that it is not open to an arbitration board to decide that certain "differences" will or will not be dealt with by the method prescribed for the settlement of differences in the collective agreement. In the Board's opinion, the combined effect of ss.61 and 48(1) of the Act is that, while a party can voluntarily cede the right to settle "differences" under the collective agreement, an arbitration board cannot take it away.

25 L.A.C. (2d) 88, award quashed by Divisional Court [unreported] and restored by Court of Appeal (note 31).

(1983), 149 D.L.R. (3d) 53 (Ont. C.A.), per MacKinnon A.C.J.O.

Supra, note 7.

R.S.O. 1970, c.232, s.37(1), re-enacted as R.S.0. 1980, c.228, s.44(1).

Supra, note 7 at 222 per Morden J.A.

Supra, note 22. 
The Board relied on recent jurisprudence which emphasizes the desirability of exclusivity of a dispute resolution mechanism for differences arising from a collective agreement. Such an approach encourages dispute resolution between employees and employers without resort to the courts and was advanced by Estey J. in St. Anne Nackawic Pulp \& Paper Co. Ltd. v. Canadian Paper Workers Union, Local 219, where he said: ${ }^{36}$

The more modem approach is to consider that labour relations legislation provides a code governing all aspects of labour relations, and that it would offend the legislative scheme to permit the parties to a collective agreement, or the employees on whose behalf it was negotiated, to have recourse to the ordinary courts, which are, in the circumstances, a duplicative forum to which the Legislature has not assigned these tasks....

Estey J. continued: $:^{37}$

...the law has so evolved that it is appropriate to hold that the grievance and arbitration procedures provided for by the Act and embodied by legislative prescription in the terms of a collective agreement provide the exclusive recourse open to parties to the collective agreement for its enforcement.

The Board noted the mandatory requirement of s.61 of the Act which is consistent with the approach taken by Estey $\mathrm{J}$.

The Board addressed the employer's counter-argument that s.61(c) supports the view that not all "differences" should be resolved by the method for settling grievances incorporated in the collective agreement. This section, the employer argued, provides expressly for the possibility that the parties may disagree about whether a "difference" should or should not be the subject of adjudication.

The Board rejected the view that s.61(c) contemplates the resolution of "differences" otherwise than by the procedure specified in the collective agreement. It considered that s.61(c) is designed to address two situations. The first is where the parties determine, by agreement, that certain "differences" will be resolved, not by adjudication, but by some other method. The second case contemplated by s.61(c) is the resolution of disputes as to whether a "difference" exists between the parties. The Board considered the purpose of s.61(c) to be to emphasize that an alleged "difference" must be an actual "difference" if it is to be the subject of adjudication under the collective agreement. ${ }^{38}$

\section{(c) Unilateral Decision of the Employer as a Method of Settlement}

The Board rejected the employer's contention that its proposals did contain a method for settlement of "differences", namely, the unilateral decision of the employer. The Board noted that, in Cherneski, the Court of Appeal held that, where one party has the unilateral right to determine an issue, no "difference" can arise within the scope of s.61. ${ }^{39}$ The Board reasoned that it followed that the method of settlement of 
"differences" contemplated by s.61 of the Act could not include the unilateral decision of one of the parties.

The Board considered, too, that the purported "settlement" of differences by the unilateral decision of one party militates against the philosophy of the Act. It noted the established doctrine in Canadian labour legislation that the no-strike clause and rights arbitration procedure are the quid pro quo for each other. ${ }^{40}$ Arguably, such a view can be applied, a fortiori, to PSERA, which imposes a total ban on strikes and significant protection of management rights. While "the method of settlement" need not be adjudication, the Board insisted that $\mathrm{s.61}$ requires that, whatever method is selected by an arbitration board, it must be a meaningful, impartial procedure. The Board held further that the unilateral determination of one party could not be considered a method for settling a difference because it effectively foreclosed the identification of any "difference". For all the foregoing reasons, the Board withheld from arbitration the employer's proposal to exclude dismissed or terminated classes of employees from the grievance and adjudication procedure.

\section{The Court of Queen's Bench Decision}

Hutchinson J. for the Court of Queen's Bench quashed the Board's decision and directed it to refer to the board of arbitration the employer's entire proposals with respect to dismissal. ${ }^{41}$ The Court held that the phrase "without recourse to the grievance procedure" was not excluded by s. 48(2) of the Act and that the Board erred in applying s. 61 of the Act to remove the clause from the arbitration board. Such error of law was patently unreasonable and grounds for the orders of certiorari and mandamus, quashing the Board's decision on non-referral and ordering it to refer the employer's proposals to arbitration.

\section{Assessment of the Court's and the Board's Decisions}

\section{(a) The Court's Decision}

The merit of Hutchinson J.'s decision is, arguably, that it produced the outcome intended by the Government in its 1985 amendment of s.61. In its decision in Crown v. A.U.P.E. ${ }^{42}$ the Board made it clear, in distinguishing Cherneski, ${ }^{43}$ that it would not submit to arbitration any proposal to deny employees access to the grievance or adjudication procedure where employees had (potential) rights under the proposed collective agreement. That decision, combined with ss.61, 63 and 48(1), served to effectively guarantee employees access to the adjudication of "differences" arising from any purported rights under the collective agreement. A union could agree to forego such access, as AUPE had done in the collective agreement that gave rise to the Cherneski 
case, but an arbitration board could not deny such access in its award if employees had a substantive right under the agreement.

While the Government did not indicate expressly its intention in amending s.61, it is a reasonable inference that it intended to remove the virtually automatic right to adjudication of "differences" implied by the Board's approach in Crown. v. A.U.P.E. Such inference is supported by the fact that, in both the pre-amendment case of Cherneski and the post-amendment Lethbridge Community College case, the respective employers advanced the argument that the "unilateral decision of the employer" is an alternative method of dispute settlement. Such argument is rather more plausible under the amended s.61 in spite of its eventual rejection by the Board.

While Hutchinson J.'s judgement may have been in line with what the government intended in its amendment of s.61, the courts are required to interpret not the government's, but the Legislature's, intention. For the latter task Hutchinson J.'s decision has a number of shortcomings. The learned Justice stated: ${ }^{44}$

I remain convinced that the employer's (proposed) articles are terms and conditions of employment...and are not excluded by s.48(2) of the Act.

Hutchinson, J. also observed: ${ }^{45}$

The question of arbitrability is limited to Part 6 of the Act where the Board's guidelines as to what is arbitrable and non-arbitrable are to be found.

Such reasoning is flawed because it overlooks s.48(1) of the Act, which reads: ${ }^{46}$

An arbitration board may consider, and an arbitral award may only deal with, those matters that may be included in a collective agreement.

This section contemplates non-arbitrable issues over and above those enumerated in s.48(2) and, contrary to Hutchinson J.'s dictum, requires the Board to look beyond Part 6 of the Act in determining questions of arbitrability. For example, the combined effect of ss.48(1) and $1(j)$ of the Act is to prevent the Board from referring to arbitration a proposal that does not pertain to a "term or condition of employment". For example, a union proposal that an educational institution shall admit only full-time students would not pertain to a term or condition of employment. Likewise, ss.93 and 94 of the PSERA would require the Board to withhold from arbitration any proposal to permit a strike or lockout during the term of the collective agreement. In both cases, the Board would invoke s.48(1) and look beyond Part 6 of the Act. This is scarcely surprising because, if we followed Hutchinson J.'s reasoning and viewed s.48(2) as defining the totality of non-arbitrable issues, s.48(1) would be redundant. 
A further criticism of the Court's decision concerns the scope of judicial review. In C.U.P.E. Local 963 v. New Brunswick Legion Corporation, Dickson J. (as he was then) described the scope of judicial review in the question: ${ }^{47}$

...was the Board's interpretation so patently unreasonable that its construction cannot be rationally supported by the relevant legislation and demands intervention by the court on review?

That approach was endorsed by Laskin C.J. for the Supreme Court of Canada in A.U.P.E. v. Olds College, ${ }^{48}$ a case arising under the Alberta Public Service Employee Relations Act. Hutchinson J. appears to have disregarded the limited scope of judicial review and acted as a court of appeal by ruling on the substantive merits of the Board's decision.

(b) The Board's Decision

The merit of the Board's interpretation of ss. 48 (1) and 61 is that it rests on the bedrock of the traditional policy of Canadian labour legislation which views the statutory provision for the adjudication of grievances as the quid pro quo for restrictions on strikes. Such policy is illustrated by Weiler's remarks: ${ }^{49}$

If the parties cannot, by their contract, permit the use of a strike to resolve a grievance, then neither can they agree to limit access to the arbitration process to secure a final and binding adjudication of that grievance.

That approach was followed by the British Columbia Labour Relations Board in Cassiar Asbestos Corporation and United Steelworkers of America, Local $6536,{ }^{50}$ a case involving the right of a probationer to take his discharge grievance to arbitration. In Cassiar, the B.C. Labour Relations Board noted that the legislation did not prohibit the parties from agreeing that a probationer had no substantive right under the collective agreement in respect of dismissal. However, it held that, if the union's grievance alleges that there is something in the agreement which limits management's freedom to terminate a probationer, the parties cannot limit access to arbitration as the remedy for securing that right. ${ }^{51}$ Of course, in arbitration, the employer may succeed in persuading the arbitrator that the grievance is without merit but the employer cannot use that as a bootstrap argument to prevent the grievance from seeing the light of day in arbitration.

In the Lethbridge Community College case, the Board adopted the approach outlined by Weiler and consistently followed by labour boards in Canada. That is not to say that the legislature is prevented from passing legislation to undermine the traditional trade-off of the prohibition of strikes and access to adjudication of grievances. However, it is to the Board's credit that it declined to topple one of the pillars of Canadian collective bargaining legislation in the absence of clear and unequivocal statutory language. 
A further merit of the Board's approach is that it is consistent with Canada's international treaty obligations. I.L.O. Convention No. 151 conceming employees' rights in the public service provides: ${ }^{52}$

[T]he settlement of disputes arising in connection with the determination of terms and conditions of employment shall be sought, as may be appropriate to national conditions, through negotiation between the parties or through independent and impartial machinery, such as mediation, conciliation and arbitration, established in such a manner as to ensure the confidence of the parties involved.

The Board's approach is also consistent with I.L.0. Recommendation No. 119 on protection against unjust dismissal. ${ }^{53}$ While Canada's international treaty obligations do not have, in themselves, the force of law in Canada, it is customary for judges to resolve ambiguity in statutory interpretation in a manner consistent with such international obligation. ${ }^{54}$

Against this, it may be contended that there is no ambiguity in the PSERA and, therefore, no need to consult international treaty obligations. It may be argued that the history of public sector collective bargaining legislation in Alberta was founded not on the trade-off of the common law right to strike for access to adjudication of grievances. Traditionally, Crown employees have been employed at the pleasure of the Crown, ${ }^{55}$ and unlike private sector employees, it is arguable, Crown servants had no common law rights to concede in return for statutorily guaranteed access to the adjudication of grievances. In short, it may be argued that the "industrial peace" argument for adjudication of grievances is inapplicable to Crown employees in Alberta because the total statutory ban on strikes merely reflects the traditional reality that Crown employees never had a common law right to strike and so "gave up" nothing when the PSERA was enacted in 1977 with a complete statutory ban on strikes.

While plausible, the foregoing argument is problematic on two counts. First, the PSERA applies not only to the Crown and its employees, but to other "public sector" areas $^{56}$ such as colleges and universities, to whom the common law "employment at pleasure" doctrine did not apply. Accordingly, non-Crown employees covered by the Act would seem to have a good claim to rely on the no-strike/grievance arbitration trade-off that underpins Canadian labour relations law.

Secondly, the mere legislative proscription of strikes does not remove those under the jurisdiction of the PSERA from the reality of industrial conflict. Even if employees obey no-strike laws, there are manifestations of "unorganized" industrial conflict such as high turnover, absenteeism, high incidence of grievances, work slowdowns, sabotage, apathy,

52.

Part V, Article 8, adopted June 27, 1978 by the General Conference of the International Labour Organization at its 64th session.

53. International Labour Conference, 47th Session, Geneva, 1963.

54. See Maxwell on the Interpretation of Statutes, 12th Edition at 183-186. Also Stag Line Limited v. Fosido Mango Co. Lid., [1932] A.C. 328 at 350 per Lord MacMillan.

35. See K.P. Swan "Public Bargaining in Canada and the U.S.: a Legal View" (1980) 19 Ind. Rel. 272 at 284; C.G. Simmons and K.P.Swan (eds.) Cases, Materials and Commentary in Labour Relations Law in the Public Sector (I.R.C.) (Ontario: Queens Univ., 1982) at 25-33.

S6. 
stress-related sickness, and drug abuse which may undermine organizational efficiency. ${ }^{57}$ The central contribution of effective and impartial grievance procedures to "industrial peace" in this broad sense is well documented ${ }^{58}$ and such procedures are arguably essential to one of the primary purposes of the PSERA, to promote an efficient public service.

It may be argued, finally, that Hutchinson J.'s approach is to be favoured over the Board's because it promotes more effectively the principle of attempting to equate employment conditions under the PSERA with those in effect in the private sector. The "comparability principle" was advanced by the government to justify s.48 of the PSERA in both the Legislative debates on the Bill ${ }^{59}$ and in the Alberta Reference ${ }^{60}$ case. Typically, unions negotiating under the Alberta Labour Relations Code seek to protect the right of casual, temporary and probationary employees to full access to grievance/arbitration procedures, if such employees are members of the bargaining unit. The result is that a significant number of, but by no means all, agreements under the Labour Relations Code give casual, temporary and probationary employees some protection against unfair dismissal and access to arbitral review.

By requiring proposals for restricted adjudicative review to proceed to arbitration, Hutchinson J. has, arguably, promoted the comparability principle by allowing an arbitration board to weigh the proposal in light of private sector norms. In contrast, the Board's approach would preclude such private/public sector comparison by an arbitration board.

It is submitted, however, that the weight of argument favours the Board's approach over that of Hutchinson, J. Yet, the Board's approach is itself deficient because it remains rooted in contractual interpretation. The Board missed an opportunity to found its decision entirely on "statutory policy" rather than on "contractual interpretation", which leaves the door open for employers with sufficient power to insist on contractual language that restricts employees' access to adjudication. The next section advances the case for a "statutory policy" approach, not only under the PSERA, but for other labour legislation in Alberta and the rest of Canada.

57. Human resources management textbooks are replete with advice, based on research findings, to assist managers in avoiding or mitigating the negative productivity effects of various aspects of such "unorganized conflict". See, for example, S.L. Dolan and R.S. Schuler, Canadian Readings in Personnel and Human Resources Management (1987, West), particularly Parts V through VII. The importance of justice and faimess to workers' motivation was recognized by A.H. Maslow, Motivation and Personality (N.Y.: Harper and Row, 1954) and they occupy the second rank of that author's celebrated "hieranchy of needs".

58. See Albert O. Hirschman, Exit, Voice and Loyalty (Cambridge, Mass: Harv. Univ. Press, 1971) for evidence and discussion of the "voice" role of grievance and arbitration procedures in a productive organization. See also Richard B. Freeman and James L. Medoff, What do Unions Do? (NY: Basic Books Inc., 1984) for the contribution of grievance/arbitration ("voice") procedures the to higher organizational productivity, at 104-109 and 176-179.

59. Legislative Committee, Debates on Bill 41, Alberta Hansard, (No. 55) 17 May 1977 at 1388-1389, per Mr. Leitch. 


\section{RECOMMENDATIONS FOR A "STATUTORY POLICY" APPROACH}

\section{A. LIMITATIONS OF THE BOARD'S APPROACH}

In the Lethbridge Community College case, the Board interpreted ss.48(1) and 61 in a manner that sought to resist what it viewed as an encroachment on the established principle of arbitral review of dismissal under a collective agreement. Nevertheless, the decision was still premised on "contractual interpretation", because the Board had to satisfy itself that the employer's proposal embodied a potential substantive right for probationary, and other employees, with respect to dismissal. Such substantive right was found to be in the employer's proposal that unsatisfactory probationers, and other employees, be dismissed at will without arbitral review. ${ }^{61}$

Such a potential substantive right enabled the Board to trigger ss.48(1) and 61 of the Act to exclude the proposal from arbitration and so from the collective agreement. However, if an employer proposed unfettered managerial power to dismiss such employees, it is virtually certain that the Board would not remove the proposal from arbitration because the absence of a proposed substantive right with respect to dismissal would render ss.48(1) and 61 inapplicable. It is submitted that the Board's approach is flawed and should be replaced by one which roots the right to arbitral review in the policy of the statute, not essentially in contractual interpretation.

Paradoxically, the flaw in the Board's approach was noted by the employer in its submissions to the Court of Queen's Bench. The employer contended that, in ruling its contract proposal non-arbitral, the Board had erroneously arrogated the jurisdiction of deciding whether a "difference" arose or might arise between the parties under the prospective collective agreement. The employer submitted that the question of whether a "difference" exists under a collective agreement is assigned by the Act to the jurisdiction of an adjudicator, not to the Board. ${ }^{62}$

In the context in which it was advanced, the employer's argument was surely specious. It was the employer's contention, for the issue at hand, that the Board should find no right to adjudication, so it is scarcely plausible that such a claim should be based on the argument that the determination of whether a "difference" exists is one to be made by an adjudicator rather than by the Board. However, while the employer's conclusion was invalid, the argument supports the view that the Board was too restrictive in its determination of matters to be withheld from arbitration by virtue of ss.48(1) and 61 of the Act.

The Board was influenced in its decision by the Metropolitan Board of Commissioners of Police ${ }^{63}$ case, where the Ontario Court of Appeal quashed the decision of an arbitrator 
who had ruled that management had exercised it discretion in an arbitrary, discriminatory and unfair manner. The Board placed weight on the Court's statement that: ${ }^{64}$

The Arbitrator erred, therefore, in finding that the grievance could be founded on a failure by the Board to exercise fairly and without discrimination, the rights conferred on it by the management rights clause. When the arbitrator determined there was no provision in the collective agreement that governed the taking of inventory and the distribution of overtime, she should have ruled that she had no jurisdiction to deal with the dispute because of an alleged improper exercise of management rights.

The Board's approach is deficient because it failed to apply properly the line of cases in which arbitrators have found an implied contractual duty on employers to exercise discretion fairly. For example, in Re Council of Printing Industries of Canada, ${ }^{65}$ the Ontario Court of Appeal was amenable to an arbitrator who found an implied contractual intent that the employer would exercise its discretion reasonably, without discrimination, bad faith or arbitrariness, notwithstanding that management's discretion may be fettered only by express language.

The issue is well stated by the British Columbia Labour Relations Board in the case of Simon Fraser University in summarizing its approach to arbitrability: ${ }^{66}$

...the preferable approach, and one that is consistent with arbitral jurisprudence, is to require that arbitrators examine the entire collective agreement to ascertain if management's decision, properly characterized on the evidence, can be found to violate any substantive provision of the agreements, even though no express provision may address the issue at hand. The absence of specific language in a collective agreement is not a complete bar to search for other sources of limitation on management's rights. While maintaining a discretion for the employer with respect to its task, this approach requires that arbitrators review the terms of a collective agreement within an interpretive framework which gives substance to the terms of an agreement, by examining its words in light of the reasonable expectations and intentions of the parties..... In doing so, it is unlikely that arbitrators would find that parties intended to permit the employer to act unfairly, arbitrarily, discriminatorily, or in bad faith.

With respect to public authorities, management powers are conferred by statute, as with the Public Service Act, ${ }^{67}$ which specifies the employer's managerial powers with respect to Alberta Crown employees. In Re Nicholson and Haldimand - Norfolk Regional Board of Commissioners of Police, ${ }^{68}$ a case involving the arbitrary dismissal of a police constable during his period of probation, the Supreme Court of Canada held that statutory power must be exercised in a manner that is fair, non-arbitrary and in good faith. The Court ordered the employer to provide the dismissed employee with reasons for his dismissal so that he may be given the opportunity to respond and permit the employer to make an informed decision.

As Thomas Kuttner observes, ${ }^{69}$ Canadian courts have taken a broad view of public employment with respect to the duty to exercise fairly managerial powers conferred by

Ibid. at 687.

65. Supra, note 31.

66. Simon Fraser University and Association of University and College Employees, Local 6. 2 C.L.R.B.R. (NS) 329, 347-348, (B.C.L.R.B.) 
statute. $^{70}$ A similar view is taken by D. Mullan in his article "Faimess in the Employment of University Faculty".71

Accordingly, at least with respect to public employment, where managerial powers are conferred by statute, ${ }^{72}$ there is a good argument for an adjudicator to find in a collective agreement an implied duty to exercise fairly, non-arbitrarily and in good faith, the powers conferred by statute and reserved for management in the collective agreement. Therefore, it is open to an adjudicator to find a substantive right for employees with respect to dismissal, even in the absence of express language in the collective agreement.

In the Lethbridge Community College case, ${ }^{73}$ the Board made two errors. First, it ignored the line of judicial authority that opens the door for an adjudicator to find, in a collective agreement, an implied duty of managerial fairness, and a substantive right for employees, with respect to dismissal. It is irrelevant that some adjudicators might not find such an implied duty in a particular case, and it is sufficient that an adjudicator might find such a duty.

Secondly, in taking upon itself the task of determining whether a substantive right with respect to dismissal would be available to probationary, casual, or other employees under the prospective collective agreement, the Board usurped the statutory jurisdiction of the adjudicator. ${ }^{74}$ Not only does the Board have no statutory power to make such a determination, ${ }^{75}$ it is peculiarly ill-equipped to do so. The Board has before it only collective bargaining proposals in dispute, not matters already agreed, or to be agreed by the parties following the implementation of the collective agreement. Also, the Board made its decision in vacuo, with no set of facts upon which an adjudicator must base his or her decision.

In summary, the Board went beyond its powers by foreclosing the opportunity for an adjudicator to rule on the question of whether a "difference" arose under the collective agreement, regardless of the presence of any express substantive right in the language of the proposal. In future, the Board should rule non-arbitral any proposed denial of arbitral review of dismissal to ensure that the statutory requirements of ss.61 and 63 are met.

Cases include Re Milljohn and the Scarborough Board of Education (1980), 112 D.L.R. (3d) 552 (Ont. Div. Ct.) (dismissal of a school teacher); Re Peterson and Atkinson (1979), 95 D.L.R. (3d) 349 (Ont. Div. Ct.) (staff appointment by hospital selection committee); Re Paine and University of Toronto (1981), 131 D.L.R. (3d) 325 (Ont. C.A.) (granting of tenure to faculty probationer).

7. (1986) 11 (2) Queen's L.J. 264.

72. See D. Mullan's discussion supra, note 71.

73. Supra, note 22.

74. It will be recalled that $\mathrm{s} .61$ of the PSERA requires a method of settling "differences" including, as the Board itself ruled, the matter of whether a "difference" exists. As the Board has ruled that the unilateral decision of management is not a method of settling "differences", such proposal must activate, automatically, s.63 of the PSERA, which gives the adjudicator the exclusive power to determine whether a "difference" exists.

75. The Board's powers enumerated in 5.9 (1) of the PSERA do not include the power to determine whether a "difference" or potential "difference" arises under a collective agreement. Such power is committed by $\mathrm{s.61}$ to the "method for settling differences" and, failing this, by s.63, to an adjudicator. 


\section{B. THE DUTY OF FAIR REPRESENTATION}

The foregoing argument contemplates challenging the arbitrability of employers' proposals, but Kuttner has advocated that bargaining proposals to restrict arbitral review of dismissal be challenged at the bargaining stage as hostile to the policy of collective bargaining legislation. ${ }^{76}$ Kuttner views the restricted access of probationary (and presumably other) employees to arbitral review as a breach of the union's duty of fair representation. He notes that, on occasion, labour boards in Canada have found a breach of such a duty where a union negotiates conditions which discriminate against a particular segment of the unit and which have no valid labour relations purpose or justification."

As Kuttner observes, no sustained rationale has been articulated as to the necessity for shielding the dismissal of certain bargaining unit members from third party scrutiny. ${ }^{78}$ With respect to probationers, it is usually argued that an employer needs time to evaluate an employee's performance, capability and suitability for permanent employment. Such judgments are based not only on objectively measurable criteria, but on many subjective, intangible factors, such as, personal character, ability to work harmoniously with others, potential for advancement and general suitability for permanent employment. With respect to casual and temporary employees, it is usually argued that management requires the flexibility of unfettered discretion in hiring and firing in order to cope with the cycles and uncertainties of production schedules. A further purported justification for restricted access to arbitration for all three categories is its widespread application.

The foregoing "justifications" are unpersuasive. The mere widespread existence of the practice no more justifies discriminatory access to arbitral review than it does sex discrimination in the workplace. While management's desire for greater discretion with respect to such employees is clearly a valid labour relations purpose, this does not require unfettered discretion with a complete absence of arbitral review of dismissal. It is customary for arbitrators to apply to probationers seeking permanent employment standards of review different from those applicable to the dismissal of seniority-rated employees. ${ }^{79}$ Arbitral jurisprudence demonstrates that the role of an arbitrator reviewing a termination for failure to meet the standards set by the employer to obtain permanent status is limited to judging the fairness and reasonableness of management's decision. In contrast, arbitrators normally examine the substantive merits of the dismissal of a seniority-rated employee. ${ }^{80}$ Likewise, different standards can be applied to casual or temporary employees.

Supra, note 69 at $307-312$.

Cases include Society of Telephone Engineers, [1977] 2 Can. L.R.B.R. 404 (C.L.R.B.) (exclusion of segment of bargaining unit from ambit of collective agreement); Radenko Bukvich. [1982] 1 Can. L.R.B.R. 422 at 427 (0.L.R.B.) (seniority, mid-term change adversely affecting minority); Paul Stuckey, [1976] O.L.R.B.R. Rep. (Dec.) 779, (seniority); Group of Seagrams Employees, [1978] 1 Can. L.R.B.R. 375 (B.C.L.R.B.) (seniority); Howard v. Northern Interior Woodworkers Assoc., (19??) 83 C.L.L.C. para. 16, 038 and 84 C.L.L.C. para. 16, 032 (seniority).

19. See, for example, Re Air Canada (1979), 23 L.A.C. (2d) 241 (Brandt).

80. Supra, note 79. See D.J.M. Brown and David M. Beatty, Canadian Labour Arbitration (2nd. ed.) (Canada Law Book, 1984) at 498-499. 
In short, the differing standards of arbitral review embody the flexibility required by employers in the dismissal of employees with less than full seniority rating. Accordingly, the demand for a discriminatory unfettered discretion has no obvious labour relations justification. Indeed, the anecdotal evidence that PSERA employers terminate probationary employees for reasons other than job performance ${ }^{81}$ lends weight to the argument that such terminations ought to be subject to third party scrutiny.

Two labour relations boards have already been receptive to Kuttner's recommended approach with respect to management attempts to restrict arbitral review of dismissal. The Canada Board ruled a union in breach of its duty of fair representation when it negotiated a clause denying probationary employees access to the grievance procedure. ${ }^{82}$ Likewise, the Ontario Board vetoed a union's attempt to negotiate a clause exempting it from representing probationers in the grievance procedure. ${ }^{83}$

While neither board went so far as to say that the mere negotiation of a discriminatory clause in a collective agreement amounts, in itself, to a breach of the duty of fair representation, the Ontario Board has ruled it a breach of the duty for the union not to consult with a group excluded from the "just cause" provision of the agreement applicable to other members of the bargaining unit. ${ }^{84}$ Furthermore, in Cuddy Food Products Ltd., the Ontario Board opened the door for a fairly heavy onus on unions to justify discriminatory access to arbitral review of dismissal, when it stated: ${ }^{85}$

A union may negotiate different terms and conditions of employment for different groups of employees within a bargaining unit without violating $\mathrm{s.68}$ (the duty of fair representation), so long as there is reasonable and objective justification for the differences and the union does not act in a manner which is arbitrary, discriminatory or in bad faith in the process by which it arrives at that result. (emphasis added)

This suggests that unions face more than a test of good faith and non-arbitrariness, and may have to submit the differential treatment of members of the bargaining unit to an objective test of reasonableness from a labour relations standpoint. ${ }^{86}$

Two difficulties attend the application of Kuttner's approach in Alberta. First, notwithstanding the Ontario Board's broad statement of principle in the Cuddy Food Products $L t d$. case, labour relations boards in Canada have been traditionally reluctant to question union bargaining priorities and to apply a test beyond one of bona fides. ${ }^{87}$ Even if there are winds of change in Ontario, a second difficulty arises from the absence of any

This allegation of a number of A.U.P.E. locals is difficult to verify because management is reluctant to provide detailed information on the number of probationary, casual and temporary employees in the bargaining unit. A refusal to provide unions with such information, on request, would probably violate the employer's duty to bargain in good faith.

82. Larry Elliston, [1982] 2 Can. L.R.B.R. 241.

83. Phillip Wayne Bradley, [1983] O.L.R.B. Rep. (March) 323.

84. See Endil Vesik (1984), 7 C.L.R.B.R. (N.S.) 317 and Jack J.A. Widdles, [1985] O.L.R.B. Rep. (Jan.).

35. Cuddy Food Products Lid. and R.W.D.S.W. 1 C.L.R.B.R. (2d) 1 at 37 (O.L.R.B.).

86. Rayonier Canada Lid., [1975] 2 Can. L.R.B.R. 196 (B.C.L.R.B.); Ward Shellington, [1975] 1 Can. L.R.B.R. 1 (O.L.R.B.), affirmed on reconsideration, [1975] 1 Can. L.R.B.R. 21.

87. For a discussion of the law and labour board policy, see Labour Law: Cases, Materials and Commentary (I.R.C. Queen's University, 4th edition) at 426-431. See also Buckvich, supra, note 77. 
explicit duty of fair representation under the PSERA. ${ }^{88}$ While a duty of fair representation might be implied under the $A c t,{ }^{89}$ there is no certainty that such an implied duty would embrace the negotiation functions of the union.

The Board or the courts might determine any implied duty under the PSERA to be comparable in scope to the express duty of the Alberta Labour Relations Code (LRC), but it is not clear whether the latter applies to the negotiation of collective agreements or only to their administration. The Code reads: ${ }^{90}$

No trade union or person acting on behalf of a trade union shall deny an employee or former employee who is or was in the bargaining unit the right to be fairly represented by the trade union with respect to his rights under the collective agreement.

It is arguable that the duty under the Code applies only to the contract adminstration phase. ${ }^{91}$ If so, Kuttner's approach would not apply to the Code, and its application to the PSERA would be uncertain. Nevertheless, Kuttner's approach is plausible in Alberta, if uncertain, at present.

\section{DUTY TO BARGAIN IN GOOD FAITH}

Labour relations boards in Canada have held that a party may breach its duty to bargain in good faith if it bargains to impasse a proposal that is prohibited by the labour relations

It is not clear whether this was an intentional or accidental omission. A statutory duty of fair representation was not introduced into the Alberta Labour Relations Code until 1980 . See note 90. The duty of fair representation doctrine was recognized prior to statutory enactment in British Columbia in Fisher v. Pemberton (1969), 8 D.L.R. (3d) 521 (B.C.S.C.). The Canada Labour Code of 1973 contained no express duty, but the Canada Labour Board inferred a duty of fair representation in Grain Handlers' Union No. I (1977), 1 C.L.R.B.R. 510. However, jurisdiction over the duty was held to lie with the courts until an express duty was introduced into the Code by S.C. 1977-78, c.27, s.49. The duty of fair representation was also found to exist in Quebec prior to an express statutory provision: see Paul-Eugene Boisvert v. Le Syndicat National des Employés de Garage de Quebec Inc., (Unreported Sept., 1980), Case no. 200-05-00182-763 (Quebec S.C.). I am indebted to a paper by W. Canning Duty of Fair Representation (Unpublished, Edmonton, Jan. 1983). See Canadian Merchant Service Guild v. Gagnon, [1984] 1. S.C.R. 509 for a discussion of the development of a "common law" duty of fair representation prior to statutory enactment by Canadian legislatures and the possibility of such a duty in the absence of express statutory language. S.A. 1988, c.L-1.2, s.151 (1). The duty was introduced in Alberta by the Labour Relations Act, S.A. 1980 c.72, s.138 (i), am. by S.A. 1981, c.69, s.15. Arguably, that amendment was designed to limit the duty to the contract administration activities of unions.

Compare the language of the Alberta Labour Relations Code (supra, note 90) with that of the Canada Labour Code, R.S.C. 1985, c.L-1, s.136.1 which is applicable only to contract administration and reads:

A trade union... shall not act in a manner that is arbitrary, discriminatory, or in bad faith in the representation of any of the employees in the unit with respect to their rights under the collective agreement that is applicable to them.

This was held in Gordon Parsley et al. and Don Kennedy, Longshoremen's Protective Union, Local 1953, 12 C.L.R.B.R. (NS) 272 to confine the duty to contract administration. It can be argued that the Alberta Code's language "with respect to his rights" could be construed as applying to rights to be negotiated as well as to rights already negotiated. 
statute or otherwise unlawful. ${ }^{92}$ So, a union seeking to include in a collective agreement a right to strike during the life of the contract would, arguably, breach its duty to bargain in good faith. Upon this analogy, Kuttner contends that: ${ }^{93}$

\begin{abstract}
Insistence by an employer upon the inclusion of a term in the collective agreement which would exclude probationers from the ambit of a just cause clause and hence place the trade union in breach of its duty of fair representation must be seen as a breach by the employer of its duty to bargain in good faith.
\end{abstract}

The limitation of this approach with respect to the PSERA is that it would require recognition of an implied statutory duty of fair representation applicable to the bargaining activities of a union. As indicated above, this cannot be taken for granted for either the PSERA or the $L R C$.

In view of the uncertain scope of the union's duty of fair representation under the PSERA, it may be preferable to base an alleged breach of duty to bargain in good faith by a PSERA employer on a violation of s.61. The Board has already held non-arbitral an employer's proposal to exclude arbitral review of dismissed probationers judged to be "unsatisfactory". The proposal was found to be in breach of s.61. Arguably, the same proposal breaches the employer's duty to bargain in good faith because it seeks to insert an unlawful provision in the collective agreement. It is submitted that, because it is always open to an adjudicator to find an implied duty of faimess on the part of management in the matter of dismissal, any proposal to exclude arbitral review of dismissal, absent some other method of the settlement of "differences" ${ }^{\text {"94 }}$ is contrary to s.61 and a breach of the duty to bargain in good faith.

Accordingly, it is submitted that, under the PSERA, a union need not wait until impasse to challenge proposals for restricted arbitral review. A challenge may be made during the bargaining phase, and a remedy sought ordering the employer to drop the offending proposal. A further advantage of founding the breach of duty on a breach of s.61, rather than on a breach of the union duty of fair representation, is that the latter rests on the

Canada Bread Co. Lid., 46 C.L.L.C. para. 16, 430 (O.L.R.B.); Utah Co. of America v. International Union of Operating Engineers, Hoisting and Portable, Union No. 870 (1959), 21 D.L.R. (2d) 166 (Sask. C.A.). Canadian Airline Pilots Assoc. and Eastern Provincial Airways Lid., S C.L.R.B.R. (NS) 368 at 410-411 (Can. L.R.B.) (Individual bargaining, unlawful under the Canada Labour Code) held to be breach of duty to bargain in good faith); Beland Co-Operative Assoc. Ltd. and Retail, Wholesale and Department Store Employees Union, Local 496, [1982] 3 Can. L.R.B.R. 448 at 450 (Sask. L.R.B.) (employee's demand to change bargaining unit in breach of duty to bargain in good faith); Town of Newcastle, New Brunswick and Canadian Union of Public Employees, Local 1275 (Police), 18 C.L.R.B.R. (NS) 277, (N.B.I.R.B.) (employer's communication with individual employees and refusal to bargain unless union abandoned right to statutory relief were unlawful and breach of duty to bargain in good faith). Camrose School District No. 1315 v. Canadian Union of Public Employees Local 1075, 19 C.L.R.B.R. (NS) 269 at 277 (A.L.R.B.). (Employer's proposals contrary to specific provisions and general scheme of the Act, held breach of duty to bargain in good faith); The duty to bargain in good faith is specified in s.39 (3) of the PSERA (supra, note 1) as am. by s.72.1 of the Public Service Employee Relations Amendment Act, S.A. 1985 c.47, s.6. The duty is specified in the Labour Relations Code (supra, note 87), and remedies in s.16(1)(c).

93. Supra, note 69 at 313.

9. As noted above, the Board has held the unilateral decision of the employer (or the union) not to be a method of settling "differences" notwithstanding the Court's decision under the Labour Relations Act in Re Royal Alexandra Hospital, supra, note 25. 
proposed differential treatment of members of the bargaining unit with respect to dismissal. The s.61 approach would embrace not only differential treatment, but a management proposal to deny arbitral review to the dismissal of all members of the bargaining unit. ${ }^{95}$

\section{SUMMARY AND CONCLUSIONS}

In the Lethbridge Community College case, the Board sought to resist the encroachment of employers and government on the access of probationary, casual and temporary employees to arbitral review of dismissal. In ruling such a proposal non-arbitrable, the Board adopted the "contractual interpretation" approach of other tribunals that have been astute to find a substantive right with respect to dismissal under the (proposed) collective agreement.

It has been contended that, while the Board's approach ought to be upheld by the Alberta Court of Appeal in the Lethbridge Community College case, the approach itself has some serious shortcomings. It was proposed that the Board acknowledge that, in the absence of some other method of settling differences, a collective agreement under the PSERA must give an adjudicator exclusive jurisdiction to settle differences and to determine whether a difference exists. Furthermore, as it is always open to an adjudicator to find an implied duty of fairness on the part of management with respect to dismissal, the Board should view as illegal any proposal that purports to exclude arbitral review of dismissal, in the absence of any other proposed method of settling "differences". Unilateral decision by management has been held by the Board not to constitute such a method of settlement.

The proposed approach would render non-arbitrable even the most draconian proposals for employer discretion with respect to the dismissal of any employee. Furthermore, it has been argued that the approach would serve as the basis for a complaint of failure to bargain in good faith on the employer's part.

It was also suggested, in line with Kuttner, that proposals for differential access to arbitral review are in potential breach of the union's duty of fair representation and may form the basis of a breach of management's duty to bargain in good faith, if such proposals are bargained to impasse.

The foregoing ideas have several merits. First, they uphold the traditional pillar of Canadian labour relations legislation that arbitral review is the quid pro quo for restricting employees' freedom to strike. Such a quid pro quo has long been considered necessary to avoid unlawful strike action or disruptive unorganized conflict, which organizational research tells us is frequently the result of perceived unfairness and a lack of employee "voice" in the workplace.

While such a proposal may seem unlikely, it would be more attractive to management if labour boards followed Kuttner's recommendation with respect to the duty of fair representation. 
Secondly, the recommended approaches protect the principle of exclusivity of labour relations remedies. If probationary or other employees are systematically denied access to collective bargaining remedies for such an important issue as dismissal, the courts will be under pressure to fill the vacuum of procedural fairness. Dismissed employees may seek common law, administrative law and even Charter remedies, ${ }^{96}$ if collective bargaining remedies are denied. While this would go against the grain of judicial policy, the courts can scarcely stand idly by as groups of employees are systematically excluded from remedies that have been misguidedly taken for granted under collective bargaining legislation. Rather than open up a Pandora's box of judicial remedies, the courts may find it attractive to endorse the approach to collective agreement remedies suggested herein.

Finally, the recommended approaches are necessary to maintain an acceptable balance of power in labour relations. Broad managerial powers to hire and dismiss probationary, temporary and casual employees will encourage the proliferation of such categories of employee and threaten union security and bargaining power. Unions are particularly vulnerable under the PSERA, and public service collective bargaining legislation in other Canadian jurisdictions, because of the de facto legal entrenchment of management rights in matters of selection, classification, organization of work, and complement of employees, among other things.

While the above proposals are directed to the PSERA, they have relevance to the Alberta Labour Relations Code and to labour legislation in other Canadian jurisdictions. 